\title{
Doing Programmatic Research: Two Case Studies from Social Psychology
}

\author{
Brandon Randolph-Seng, M.S. ${ }^{1}$
}

\begin{abstract}
As a new researcher, transferring knowledge of the scientific process into an actual contribution to that process can be difficult. The purpose of this article is to first demonstrate how a deductive vs. inductive approach can be implemented in a program of research, and second to provide insights on using each approach in the science of psychology. Specifically, the histories of Michael A. Hogg's and John A. Bargh's programmatic research will be traced, followed by a critical comparison of each method. Finally, insights on doing programmatic research in psychology will be discussed.
\end{abstract}

1: Department of Psychology, Texas Tech University, Lubbock, TX, USA.

Author Note: Brandon Randolph-Seng's work on this article was completed in partial fulfillment of his $\mathrm{PhD}$ qualifying exams at Texas Tech University, which was supervised by Darcy A. Reich.

Address correspondence to Brandon Randolph-Seng: b.randolph-seng@ttu.edu.

NSPB: 2006 - Vol. 4, No. 2 


\section{Introduction}

Psychology is a science. Implicit in this first sentence are terms like the scientific method, the research process, and critical thinking. However, transferring knowledge of the scientific process into an actual contribution to that process can be difficult (Zacks \& Roediger, 2004). For example, the classic scientific method model consists of two complementary forms of reasoning: induction and deduction. Therefore, factual findings can either contribute to theory development (induction) or theory can serve as a basis for hypotheses that may or may not be verified by factual findings (deduction). How does a beginning researcher know if an inductive vs. deductive approach is the right approach to take? Further, how can the chosen approach be implemented into a tangible program of research? The purpose of the discussion below will be to first demonstrate how a deductive vs. inductive approach can be implemented in a program of research, and second to provide insights on using each approach in the science of psychology.

\section{Programmatic Research}

The scientific method is a cyclical process. As such, creating a program of research is a necessary component to being a scientist in psychology (Proctor \& Capaldi, 2001). Programmatic research is a systematic step-by-step approach to theory development. As implied above, it may proceed in either an inductive or deductive path; however, a logical progression from experiment to experiment must be evident. Research done in psychology has become mostly programmatic in nature. Therefore, in order to make a contribution to the understanding of human thought and behavior, contemporary researchers must have a program of research in place (Klahr \& Simon, 2001). A good example of the trend towards doing programmatic research comes from social psychology. For example, social psychological research has

NSPB: 2006 - Vol. 4, No. 2 
increasingly emphasized programmatic progression within a single journal article (Devine \& Brodish, 2003). For this reason, this discussion will focus on two contemporary social psychologists that stand out as programmatic researchers: Michael A. Hogg of Claremont Graduate University, and John A. Bargh, of Yale University. These researchers pair nicely as complementary case studies given Hogg's deductive or top-down approach, and Bargh's use of an inductive or bottom-up approach. The histories of Hogg's and Bargh's research programs will first be traced, followed by a critical comparison of each approach, which in turn will lead to insights on doing programmatic research in psychology.

\section{Case Study 1}

As a graduate student of John C. Turner at Bristol University, Hogg had extensive training in the social identity tradition Turner was one of the first researchers to formalize the social identity theory. ${ }^{1}$ However, the programmatic research conducted by Hogg was not merely a continuation of Turner's research on social identity theory, but a top-down deductive process of working within the metatheory in which social identity theory was embedded (Abrams \& Hogg, 2004).

Hogg's published program of research began in 1985 with his study on gender salience and stereotypical speech (Hogg, 1985), as well as his study on gender identification and educational and occupational outcomes of adolescents (Abrams, Sparkes, \& Hogg, 1985). These first few studies were set within a social identity perspective rather than theory. For example, while social identity theory was originally aimed at prediction of specific

1: The main postulate of social identity theory is that the self can be defined by group membership which is driven by a desire for a positive self-concept through identification with groups that maintain positive evaluations in certain intergroup contexts (see Tajfel \& Turner, 1979).

NSPB: 2006 - Vol. 4, No. 2 
intergroup behavior, Hogg investigated the broader applications of the theory, such as gender identification. With additional empirical demonstrations and applications to interpersonal attraction, conformity, and self-conception (Hogg, Abrams, \& Patel, 1987; Hogg \& Turner, 1985; Hogg \& Turner, 1987), the stage was set for Hogg to formalize his social identity perspective into the book, Social Identifications: A Social Psychology of Intergroup Relations and Group Processes in 1988. This book attempted to apply the social identity concept to many of the phenomenon-specific theories dominant at that time in social psychology, and provided a specific plan for Hogg's developing research program to follow. Therefore, Hogg's programmatic research (from 1988 on) involved a deductive process that sought to verify specific hypotheses concerning the social identity perspective. This deductive process can be seen with a series of empirical studies between 1989 and 1995 that specifically tested the hypothesis that social norms drive conformity and group polarization (see Hogg, Hardie, \& Reynolds, 1995).

As part of its broad framework, the Hogg and Abrams' (1988) book provided an integration of the social-cognitive emphasis of self-categorization theory and the more macro level motivational emphasis of social identity theory (Abrams \& Hogg, 2004). ${ }^{2}$ Hogg's empirical research allowed him to go beyond some of the formal hypotheses about collective and self-motivational processes in social identification (Abrams \& Hogg, 1988) to specify a broader motive, that of uncertainty reduction. ${ }^{3}$ This

2: Self-categorization theory states that people cognitively categorize themselves on a continuum ranging from "unique individual" to "human being". The current salience of a particular social category determines what self-categorization is adopted at that moment in time (see Turner, Hogg, Oakes, Reicher, \& Wetherell,1987).

3: The uncertainty reduction motive is thought to be a direct motivation driving social identity processes. The idea is that we have a need to reduce feelings of uncertainty in our world; therefore, we categorize ourselves and others (see Hogg \& Abrams, 1993).

NSPB: 2006 - Vol. 4, No. 2 
formalization led in turn to work exploring specific intragroup behavior, such as the rejection of deviant members (Marques, Abrams, Páez, \& Hogg, 2001). Therefore, in the case of motivational influences in groups, Hogg's hypothesis verification process led to a fuller understanding of group motivation while still holding to the guiding forces of his social identity perspective.

Hogg's theoretical assumption that his social identity perspective was a general theory of group membership allowed him to focus on many different levels of analysis - from macro level groups (social identity theory) to individual group processes (selfcategorization theory) to small micro level groups (e.g., Hogg, 1996). Therefore, in addition to the research examining deviant group members mentioned above (see also Fielding, Hogg, \& Annandale, 2006), Hogg's research has increasingly focused on leadership (e.g., Hogg et al., 2005), roles (e.g., Hogg, Abrams, Otten, \& Hinkle, 2004), influence (e.g., Duck, Hogg, \& Terry, 1999), and discussion (e.g., Abrams, Hogg, Hinkle, Often, \& Poole, 2005) within small groups.

With the integration of the small group level of analysis into his program of research, Hogg has shown that social environmental influences (that have previously been assumed to result from personal traits of group members) affect individuals on a more collective level (Abrams \& Hogg, 2004). For example, even the attitude - behavior relation can be better understood in the context of normative behaviors of the group (e.g., White, Hogg, \& Terry, 2002).

In sum, Hogg's top-down methodology has contributed to the breadth of his empirical studies and the application of his theory into new territory. His approach has allowed him to formally specify hypotheses that were indirectly set forth in social identity theory and self-categorization theory and to verify 
alternative mechanisms consistent with an overall social identity perspective. Nevertheless, Hogg and Abrams (1988) had the foresight to specify some of the problems of integrating the social identity perspective with a more real world symbolic interactionist perspective. ${ }^{4}$ In an effort to test the boundary conditions of his perspective (consistent with a deductive program of research), Hogg has conducted applied research outside of the lab (e.g., White, Terry, \& Hogg, 1994). This applied research connected Hogg's perspective to the symbolic interactionist perspective, allowing for an exploration of the dynamic properties between individual and group processes (Hornsey \& Hogg, 2000). Ultimately, Hogg's program of research has focused on answering the question 'How do we determine who we are?' through the deductive force of his social identity perspective (Abrams \& Hogg, 2004).

\section{Case Study 2}

As a graduate student of Robert B. Zajonc at the University of Michigan, Bargh received extensive training in social-cognitive methodology (see Kunst-Wilson \& Zajonc, 1980). However, Zajonc's and Bargh's interests diverged; the former was more interested in automatic affective processes, and the latter focused on automatic cognitive processes. ${ }^{5}$

Bargh's program of research began with his dissertation and subsequent publication in 1982. Based on person perception

4: The symbolic interactionist perspective states that individuals approach objects (people) in their world based on the meaning they have derived for those objects; and these meanings originate from real life social interactions and interpretation of such interactions (see Blumer, 1969).

5: Automatic processes involve reflexive responses to certain triggering conditions. These processes require only that a stimulus event or object be detected by an individual's sensory system. Once that triggering event is detected, the process runs to completion without conscious awareness (see Bargh, 1989).

NSPB: 2006 - Vol. 4, No. 2 
theory, Bargh's research was a verification of the automatic mental processes implied in past research findings. For example, Bargh and Pietromonaco's (1982) research was basically a replication of Higgins, Rholes, and Jones' (1977) research on the use of category traits as primes, but with an important difference of using nonconscious rather than conscious primes to verify that the process of trait priming could occur in an automatic fashion. 6 Bargh was also concerned with integrating the influence of primed and chronic personality traits on the perception of others. Connecting these concerns with his 1982 research on the automatic influence of self-relevant information led Bargh into a series of studies from 1985 to 1988. These studies demonstrated that chronic personality traits and temporarily primed traits can have identical and even additive influences on person perception (e.g., Bargh, Lombardi, \& Higgins, 1988).

In 1989, Bargh reviewed the social psychological literature on the automatic influence of the environment on thought, judgment, and behavior. He concluded that automatic influences of the environment are restricted to thought and judgment and not behavior. Nevertheless, Bargh started to induce that automatic mental processes may also apply to goals and motivations (see Bargh, 1990). This work led to the creation of the auto-motive model and the conclusion that the environment may be able to automatically trigger behavior nonconsciously (Bargh, 2003). Bargh integrated the auto-motive model with previous work on chronic personality traits in order to study depression (Andersen, Spielman, \& Bargh, 1992) and sexual harassment (Bargh, Raymond, Pryor, \& Strack, 1995). This set the stage for Gollwitzer and Bargh (1996) to specify how goals could be auto-

6: Priming is the activation of a cognitive representation in one context in order to nonconsciously influence an unrelated context. Priming techniques may be either supraliminal (conscious) or subliminal (nonconscious). Without the use of subliminal priming, it is not possible to rule out the involvement of conscious mental processes (see Bargh \& Chartrand, 2000). 
matically triggered from the environment.

Next, Bargh posited that another route to automatic behavior, besides motivation, is a direct perception-behavior connection. Bargh, Chen and Burrows found evidence for such a connectionthrough a series of experiments published in 1996. For example, they found that participants primed with elderly words (e.g. Florida, retirement) actually walked slower than a control group. When the results of the Bargh et al. (1996) studies first came out, even Bargh (2003) admitted that he was surprised. This surprise is characteristic of an inductive research process in which empirical studies inform theory formulation.

Over the next few years, Bargh and others applied the notion of the automatic perception-behavior link to such diverse phenomena as behavior confirmation (e.g., Chen \& Bargh, 1997) and imitation (e.g., Chartrand \& Bargh, 1999). Having clearly established the automatic perception-behavioral link across many domains, Bargh concentrated instead on the automatic effects of goals on behavior, firmly establishing this connection in 2001 (Bargh, Gollwitzer, Lee-Chai, Barndollar, \& Trãktschel, 2001). With Bargh's programmatic research now successfully demonstrating the automatic influence of cognitive and motivational processes on social perception, judgments, and behavior, he has increasingly sought out 'second generation questions' (see Bargh, 2006) such as understanding the automatic self-regulation of goals (Fitzsimons \& Bargh, 2004).

Despite the rich empirical demonstrations of automaticity in social life provided by Bargh's programmatic research, the bottom-up inductive enterprise of automaticity research has led Bargh (2006) to recently ask, "What have we been priming all these years?" (p. 147). The realization that many of the recent findings in automaticity research have moved beyond the original social perception and behavior interpretations has 
motivated Bargh to inductively seek out a broader theoretical framework to make sense of the findings that have marked his research program.

As part of this effort, Bargh has begun to turn from the cognitive systems approach that previously defined his research, to a more functional approach in which the automatic effects of priming are thought to lead to the activation of numerous action plans linked to an object (Bargh, 2006). This line of thinking seems to have brought Bargh back to his roots, as he is beginning to look at the automatic influence of emotional-evaluative content (as opposed to cognitive-evaluative content) in social life (e.g., Chartrand, van Baaren, \& Bargh, 2006).

In sum, Bargh's methodology is a bottom-up endeavor in which the theoretical connection from study to study is induced from previous research results. Despite his inductive strategy, theory is still the driving force. In other words, Bargh conducts research in order to inform and revise theory. Such an approach allows Bargh to selectively and logically apply his results to new areas previously disconnected (e.g., Chartrand, van Baaren, \& Bargh, 2006). Nevertheless, application of nonconscious social phenomena outside of the lab has been difficult. This difficulty has caused Bargh to reanalyze his cognitive system perspective and to begin a more functionalistic approach to research. Bargh notes that such an approach should allow his past research findings to become more integrated with a symbolic interactionist perspective (Bargh, 2006). Ultimately, Bargh's program of research has focused on answering the question 'How much free will do we have?' through the inductive force of his theorydriven perspective.

\section{Comparing the Two Cases}

In comparing the programmatic research of Hogg and Bargh, 
some interesting differences and similarities emerge. The discussion below will first focus on the differences between these two research programs and then will conclude with the similarities.

\section{The Differences}

First, as mentioned above, Hogg's research program follows a deductive top-down process and focuses on concretely articulating the boundaries of his social identity perspective, while Bargh's research program follows an inductive bottom-up process with a focus on understanding, verifying, and improving the knowledge base regarding nonconscious social phenomenon. This difference in style may explain differences in research outcomes, such that Hogg has investigated the more functional components of social phenomena, and Bargh has investigated the more cognitive components of social phenomena.

Second, Hogg's research program has been based on a predetermined plan. His social identity perspective contains a number of theoretically consistent and formally unified subtheories. Instigating a top-down program of research has been productive because of Hogg's clarity concerning the relationship between the measures and methods used and the mechanisms underlying specific empirical demonstrations (Abrams \& Hogg, 2004).

In contrast, Bargh's research program has not been driven by a predetermined plan. His social cognitive perspective is relatively piecemeal; this perspective contains distinct theories that are inductively combined to make sense of ever expanding empirical results. Nevertheless, conducting a bottom-up program of research has been productive because of Bargh's painstaking emphasis on the details of the methods used to formally conclude that an effect has occurred. 
Third, when Hogg's research went beyond some formal hypothesis, as in the case of uncertainty reduction motivations, it was usually in the service of his metatheory. For Bargh, his theory is often in the service of his results, as in the case of his efforts in trying to apply automaticity findings beyond the lab.

In sum, the programs of research conducted by Hogg and by Bargh fundamentally differ in style. Nevertheless, many of the differences that emerge in the programs of these two researchers may have more to do with the traditions from which they emerged than the programs of research themselves. During the time that both of these researchers were in graduate school, there was a rift between North American and European social psychological research. In North America, theory building was mainly a methodological, gradual, bottom-up approach. Each hypothesis was specifically tested within a restricted paradigm with an emphasis on improved measurement and theory. In contrast, in European social psychology, theory building was mainly an overarching, theoretical, top-down approach. Research was not about whether a hypothesis was supported by a specific result, but whether the theoretical assumption of the design was reasonable to begin with (Abrams \& Hogg, 2004). Therefore, it is understandable that Hogg would be influenced by the European school of thought as a student at Bristol University and Bargh would follow the North American school of thought as a student at the University of Michigan.

\section{The Similarities}

There are similarities between Hogg's and Bargh's research. First, both researchers have had extremely successful careers and are considered by their peers to have substantially contributed to the understanding of social psychology. For example, each researcher has been highly productive in producing empirical results. This similarity in knowledge production between these two very different research programs is related to the similar 
importance each researcher places on understanding operational components of what the empirical demonstration means in light of a more conceptual level of analysis. In other words, both researchers are good at doing basic research.

A second similarity is that both Bargh's and Hogg's research programs are ultimately concerned with theory-building. Both research programs have provided an integration of theory across a diverse number of social psychological phenomena (which has also contributed to their publication success). Also, both research programs have found success in separating cognitive from motivational components in the social phenomena of interest. This similarity may have more to do with the time period under investigation, with a general shift in social psychology from cognition to motivation.

Lastly, and probably most interesting, is the similar place that Hogg and Bargh have ended up in their research programs to date: both have a desire for an understanding of how their particular perspective and/or findings relate to dynamic social behavior outside of the lab. Because of this shared interest, the two perspectives may become integrated in the future.

\section{Insights on Doing Programmatic Research in Psychology}

In reviewing Hogg's and Bargh's work, some principles concerning programmatic research in psychology become apparent. The first and most obvious insight is that using programmatic research can be a very effective way of conducting research in psychology. Just glancing at the amount of research these two researchers and their collaborators have published is astounding. Second, not only is programmatic research an efficient way of doing research, but it focuses the researcher on the importance of the methodologies underlying the process (e.g., understanding 
what is being manipulated at a conceptual level).

Comparing these two programs also reveals that there are advantages and disadvantages to both top-down and bottom-up theory building processes. When using a top-down process, the advantage is that a guide can be provided at a functional level while the disadvantage is that the researcher can ignore or misinterpret unexpected findings. For a bottom-up process, the advantage is that the researchers are free to explore many possibilities in their research, thus allowing for a fast accumulation of evidence, although they may be unable to always clearly explain why they found what they did. Nevertheless, a bottom-up inductive process will more naturally allow for a functional perspective to emerge (see Platt, 1964). Finally, programmatic research has at its core an integration of theory. Whether an inductive or deductive strategy is used, both programs of research reviewed in this paper attempted to integrate and build an understanding of the social reality of interest at a theoretical level.

In conclusion, doing programmatic research in psychology allows for the development of theory. As the two case studies demonstrate, programmatic research is an important (if not necessary) component to the development of psychology as a science.

\section{References}

Abrams, D., \& Hogg, M. A. (1988). Comments on the motivational status of self-esteem in social identity and intergroup discrimination. European Journal of Social Psychology, 18, 317-334.

Abrams, D., \& Hogg, M. A. (2004). Metatheory: Lessons from social identity research. Personality and Social Psychology Review, 8, 98-106. 
Abrams, D., Hogg, M. A., Hinkle, S., Often, S., \& Poole, M. S. (2005). The social identity perspective on small groups. In M. S. Poole \& A. B. Hollingshead (Eds.), Theories of small groups: Interdisciplinary perspectives. (pp. 99-137). Thousand Oaks, CA: Sage.

Abrams, D., Sparkes, K., \& Hogg, M. A. (1985). Gender salience and social identity: The impact of sex of siblings on educational and occupational aspirations. British Journal of Educational Psychology, 55, 224-232.

Andersen, S. M., Spielman, L. A., \& Bargh, J. A. (1992). Futureevent schemas and certainty about the future: Automaticity in depressives' future-event predictions. Journal of Personality and Social Psychology, 63, 711-723.

Bargh, J. A. (1982). Attention and automaticity in the processing of self-relevant information. Journal of Personality and Social Psychology, 43, 425-436.

Bargh, J. A. (1989). Conditional automaticity: Varieties of automatic influence in social perception and cognition. In J. S. Uleman \& J. A. Bargh (Eds.), Unintended thought. (pp. 3-51). New York: Guilford Press.

Bargh, J. A. (1990). Auto-motives: Preconscious determinants of social interaction. In E. T. Higgins \& R. M. Sorrentino (Eds.), Handbook of motivation and cognition: Foundations of social behavior (Vol. 2, pp. 93-130). New York: Guilford Press.

Bargh, J. A. (2003). Why we thought we could prime social behavior. Psychological Inquiry, 14, 216-218.

Bargh, J. A. (2006). What have we been priming all these years? On the development, mechanisms, and ecology of nonconscious social behavior. European Journal of Social Psychology, 36, 147-168.

Bargh, J. A., \& Chartrand, T. L. (2000). The mind in the middle: A practical guild to priming and automaticity research. In $\mathrm{H}$. T. Reis \& C. M. Judd (Eds.), Handbook of research methods in social and personality psychology (pp. 253-285). New 
York: Cambridge University Press.

Bargh, J. A., Chen, M., \& Burrows, L. (1996). Automaticity of social behavior: Direct effects of trait construct and stereotype activation on action. Journal of Personality and Social Psychology, 71, 230-244.

Bargh, J. A., Gollwitzer, P. M., Lee-Chai, A., Barndollar, K., \& Trãktschel, R. (2001). The automated will: Nonconscious activation and pursuit of behavioral goals. Journal of Personality and Social Psychology, 81, 1014-1027.

Bargh, J. A., Lombardi, W. J., \& Higgins, E. T. (1988).

Automaticity of chronically accessible constructs in person $\mathrm{X}$ situation effects on person perception: It's just a matter of time. Journal of Personality and Social Psychology, 55, 599605.

Bargh, J. A., \& Pietromonaco, P. (1982). Automatic information processing and social perception: The influence of trait information presented outside of conscious awareness on impression formation. Journal of Personality and Social Psychology, 43, 437-449.

Bargh, J. A., Raymond, P., Pryor, J. B., \& Strack, F. (1995). Attractiveness of the underling: An automatic power [to] sex association and its consequences for sexual harassment and aggression. Journal of Personality and Social Psychology, 68, 768-781.

Blumer, H. (1969). Symbolic interaction: Perspective and method. Englewood Cliffs, NJ: Prentice-Hall.

Chartrand, T. L., \& Bargh, J. A. (1999). The chameleon effect: The perception-behavior link and social interaction. Journal of Personality and Social Psychology, 76, 893-910.

Chartrand, T. L., van Baaren, R. B., \& Bargh, J. A. (2006). Linking automatic evaluation to mood and information processing style: Consequences for experienced affect, impression formation, and stereotyping. Journal of Experimental Psychology: General, 135, 70-77.

Chen, M., \& Bargh, J. A. (1997). Nonconscious behavioral 
confirmation processes: The self fulfilling consequences of automatic stereotype activation. Journal of Experimental Social Psychology, 33, 541-560.

Devine, P. G., \& Brodish, A. B. (2003). Modern classics in social psychology. Psychological Inquiry, 14, 196-202.

Duck, J. M., Hogg, M. A., \& Terry, D. J. (1999). Social identity and perceptions of media persuasion: Are we always less influenced than others? Journal of Applied Social Psychology, 29, 1879-1899.

Fielding, K. S., Hogg, M. A., \& Annandale, N. (2006). Reactions to positive deviance: Social identity and attribution dimensions. Group Processes \& Intergroup Relations, 9, 199-218.

Fitzsimons, G. M., \& Bargh, J. A. (2004). Automatic self regulation. In R. F. Baumeister \& K. D. Vohs (Eds.), Handbook of self-regulation: Research, theory, and applications. (pp. 151-170). New York: Guilford Press.

Gollwitzer, P. M., \& Bargh, J. A. (1996). The psychology of action: Linking cognition and motivation to behavior. New York: Guilford Press.

Higgins, E. T., Rholes, W. S., \& Jones, C. R. (1977). Category accessibility and impression formation. Journal of Experimental Social Psychology, 13, 141-154.

Hogg, M. A. (1985). Masculine and feminine speech in dyads and groups: A study of speech style and gender salience. Journal of Language and Social Psychology, 4, 99-112.

Hogg, M. A. (1996). Social identity, self-categorization, and the small group. In E. H. Witte \& J. H. Davis (Eds.) Understanding group behavior: Vol. 2. Small group processes and interpersonal relations. (pp. 227-253). Mahwah, NJ: Lawrence Erlbaum.

Hogg, M. A., \& Abrams, D. (1988). Social identifications: A social psychology of intergroup relations and group processes. London \& New York: Routledge.

Hogg, M. A., \& Abrams, D. (1993). Towards a single-process 
uncertainty-reduction model of social motivation in groups. In M. A. Hogg \& D. Abrams (Eds.), Group motivation: Social psychological perspectives (pp. 173-190). Hertfordshire, UK: Harvester Wheatsheaf.

Hogg, M. A., Abrams, D., Otten, S., \& Hinkle, S. (2004). The social identity perspective: Intergroup relations, selfconception, and small groups. Small Group Research, 35, 246-276.

Hogg, M. A., Abrams, D., \& Patel, Y. (1987). Ethnic identity, self-esteem, and occupational aspirations of Indian and Anglo-Saxon British adolescents. Genetic, Social, and General Psychology Monographs, 113, 487-508.

Hogg, M. A., Hardie, E. A., \& Reynolds, K. J. (1995). Prototypical similarity, self categorization, and depersonalized attraction: A perspective on group cohesiveness. European Journal of Social Psychology, 25, 159-177.

Hogg, M. A., Martin, R., Epitropaki, O., Mankad, A., Svensson, A., \& Weeden, K. (2005). Effective leadership in salient groups: Revisiting leader-member exchange theory from the perspective of the social identity theory of leadership. Personality and Social Psychology Bulletin, 31, 991-1004.

Hogg, M. A., \& Turner, J. C. (1985). Interpersonal attraction, social identification and psychological group formation. European Journal of Social Psychology, 15, 51-66.

Hogg, M. A., \& Turner, J. C. (1987). Social identity and conformity: A theory of referent information influence. In W. Doise \& S. Moscovici (Eds.), Current issues in European social psychology (Vol. 2, pp. 139-182). Cambridge, UK: Cambridge University Press.

Hornsey, M. J., \& Hogg, M. A. (2000). Assimilation and diversity: An integrative model of subgroup relations. Personality and Social Psychology Review, 4, 143-156.

Klahr, D., \& Simon, H. A. (2001) What have psychologists (and others) discovered about the process of scientific discovery? Current Directions in Psychological Science, 10, 75-79. 
Kunst-Wilson, W. R., \& Zajonc, R. B. (1980). Affective discrimination of stimuli that cannot be recognized. Science, 207, 557-558.

Marques, J. M., Abrams, D., Páez, D., \& Hogg, M. A. (2001). Social categorization, social identification, and rejection of deviant group members. In M. A. Hogg \& R. S. Tindale (Eds.), Blackwell handbook of social psychology: Group processes (pp. 400-424) Oxford, UK: Blackwell.

Platt, J. R. (1964). Strong Inference. Science, 146, 347-353.

Proctor, R. W., \& Capaldi, E. J. (2001). Empirical evaluation and justification of methodologies in psychological science. Psychological Bulletin, 127, 759-772.

Tajfel, H., \& Turner, J. C. (1979). An integrative theory of intergroup conflict. In W. G. Austin \& S. Worchel (Eds.), The social psychology of intergroup relations (pp. 33-47). Monterey, CA: Brooks/Cole.

Turner, J. C., Hogg, M. A., Oakes, P. J., Reicher, S. D., \& Wetherell, M. S. (1987). Rediscovering the social group: A self-categorization theory. Oxford, UK: Blackwell.

White, K. M., Hogg, M. A., \& Terry, D. J. (2002). Improving attitude-behavior correspondence through exposure to normative support from a salient ingroup. Basic and Applied Social Psychology, 24, 91-103.

White, K. M., Terry, D. J., \& Hogg, M. A. (1994). Safer sex behavior: The role of attitudes, norms, and control factors. Journal of Applied Social Psychology, 24, 2164-2192.

Zacks, J. M., \& Roediger, H. L., III. (2004). Setting up your lab and beginning a program of research. In J. M. Darley, M. P. Zanna, \& H. L. Roediger III (Eds.), The complete academic: A career guide (2nd ed., pp. 135-152). Washington, DC: American Psychological Association. 